\title{
Pacific islands: Development vulnerabilities, international response and structural transformation
}

\author{
Andrzej Bolesta ${ }^{1}$ \\ United Nations Economic and Social Commission for Asia and the \\ Pacific \\ ORCID 0000-0003-2298-6133
}

\begin{abstract}
The goal of this paper is, upon presenting Pacific island countries' development challenges and vulnerabilities, to examine and propose possible policy solutions. In view of very particular development challenges related to economic, environmental and social vulnerabilities, the discussion is taking place concerning (a) the content of the UN programmes of actions to support small island developing States (SIDS); (b) the genus of their preferred structural economic transformation and (c) the supporting economic policies. This paper argues that in order to address various development predicaments of small island developing State (a) international community must be engaged in the areas described in the UN programmes of action, as some environmental and economic challenges such as climate change, environmental degradation and external economic shocks cannot be addressed exclusively through domestic policies; (b) particular type of structural economic transformation must take place, which deviates from the traditional path from agriculture to industry and to services, since for the overwhelming majority of SIDS manufacturing is not a viable option due to their remote location and small population, which make them unattractive for international investments and thus regional and global value chains; (c) the specific type of structural transformation must be underpinned by effective economic policies focusing on building resilience.
\end{abstract}

Keywords: development, structural transformation, economic policies, Pacific islands

JEL Classification: O10, O20, E60

${ }^{1}$ The views expressed herein are those of the author and do not necessarily reflect the views of the United Nations. 


\section{INTRODUCTION}

Despite common perceptions to the contrary, Pacific islands are a very diverse group of countries. Divided into three geographic sub-regions - Melanesia, Micronesia and Polynesia, they differ in size of their national economies, size of their landmass and populations, international status and development level. Melanesian countries possess the largest landmass with Papua New Guinea (PNG), occupying 58\% of the island of New Guinea and standing out with 452.9 thousand square km, whereas Micronesian and Polynesian states are small atolls or groups of atolls, with Nauru having merely $21 \mathrm{sq}$. km and Tokelau only $12 \mathrm{sq} . \mathrm{km}$. The populations range from 1.6 thousand in Niue to 8.6 million in PNG. The Gross Domestic Product (GDP) per capita ranges from US\$1,625 in Kiribati to US\$17,318 in Palau (World Bank, 2019), if one does not consider the much richer Guam and Northern Mariana Islands, which are part of the United States. Many Pacific islands are independent states, some however, are either overseas territories of larger countries (e.g., French Polynesia, New Caledonia, Wallis and Futuna, Tokelau), or associated territories (e.g., American Samoa, Niue, Northern Mariana Islands, Cook Islands).

As a result of their geographic and economic features, since 1992 these countries have been officially called: Small Island Developing States (SIDS). Although Pacific SIDS are very different from each other, they face common development challenges which significantly impede their economic and social progress; "small but growing populations, limited resources, remoteness, susceptibility to natural disasters, vulnerability to external shocks and fragile environments. Their growth and development are also held back by high communication, energy and transportation costs, disproportionately expensive public administration and infrastructure due to their small size, and little to no opportunity to create economies of scale."2

This article focuses on Pacific SIDS which are independent states. In that group, five states, namely, Kiribati, Solomon Islands, Timor-Leste, Tuvalu and Vanuatu are not only classified as SIDS, but also as Least Developed Countries (LDCs) - a United Nations' category used since 1971 - due to their low level of development. The article attempts to define the pool of necessary structural changes and policy actions to address SIDS' development predicaments. Section One examines the existing development literature on Pacific SIDS and identifies their development vulnerabilities. Section Two examines the framework of international engagement and support provided to SIDS. Section Three analyses the particular features of structural economic transformation, which is pertinent to SIDS. Section Four lists the necessary supporting economic policies. The methodology used in the paper is based on author's grassroot research conducted while he worked with policymakers in Pacific SIDS in the years 2017-2020, and is underpinned by the review of secondary literature, mostly regional development reports.

\section{DEVELOPMENT VULNERABILITIES}

The literature concerned with Pacific SIDS' development is scarce and is almost exclusively limited to reports by international bodies (e.g. by Economic and Social Commission for Asia and the Pacific, United Nations Conference on Trade and Development, The World Bank, United Nations Department of Economic and Social Affairs, the Organisation of Economic Cooperation and Development), national governments with vested economic and political interest in the region (e.g. the governments of Australia, New Zealand, Japan), and international foundations (e.g. Lowy Institute, Rockefeller Foundation). Some insightful reports are also produced by regional bodies such as Pacific Forum and independent academics.

${ }^{2}$ Wikipedia: https://en.wikipedia.org/wiki/Small Island Developing States (accessed: 17/07/19). 
However, the number of scholars examining Pacific SIDS is limited and these are usually located in the closely located advanced economies (Australia and New Zealand), former colonial powers (France and the UK) and Fiji. As far as particular development topics in Pacific SIDS are concerned, for example, a recent ESCAP's (2020a) Asia-Pacific Countries with Special Needs Development Report discusses their development prospects in reference to their oceanic resources, singling out tourism and fisheries as the most important sectors. World Bank (2017) also discusses seabed mining in this respect, whereas ESCAP's 2019 report suggests modernisation and commercialisation of agriculture. Another ESCAP report pays more attention to closer regional cooperation as the means to overcome Pacific SIDS' development challenges (ESCAP, 2020b). So does UNCTAD's (2014) report, which emphasizes the role of trade. Considering particular development predicaments of SIDS, the emerging literature concerns climate change and environmental degradation as the main developmental predicaments (see: Holland and Kay, 2013; Devadason et al. 2013; Lum and Vaughn, 2017). Some attention is directed at particular sectors such as tourism (Pratt, 2015, 2019; UNWTO, 2019), fisheries (Gillet, 2009, 2016; FAO, 2016, 2018), political stability (Firth, 2018; Brown, 2006; ESCAP, 2018).

Indeed, Pacific small island developing States, due to their small nevertheless diverse populations, limited landmass and small economies (see Table 1), as well as geographic locations and remoteness from international markets, are among the most vulnerable countries in the world. They are exposed to a variety of external shocks and internal predicaments that can be classified as economic, environmental, social and political.

Table 1

SIDS in nutshell, 2018 or latest year available

\begin{tabular}{|l|c|c|c|c|c|}
\hline States & $\begin{array}{c}\text { Population* } \\
\text { (in } \\
\text { thousands) }\end{array}$ & $\begin{array}{c}\text { Landmass } \\
\text { (in km2)** }\end{array}$ & $\begin{array}{c}\text { GDP* } \\
\text { (current) } \\
\text { (US\$ in } \\
\text { millions) }\end{array}$ & $\begin{array}{c}\text { GDP per } \\
\text { capita* } \\
\text { (current) } \\
\text { (US\$) }\end{array}$ & $\begin{array}{c}\text { LDC } \\
\text { category }\end{array}$ \\
\hline Fiji & 833.5 & 18,274 & $5,479.5$ & 6,202 & \\
\hline Kiribati & 115.9 & 811 & 188.3 & 1,625 & Y \\
\hline Marshall Islands & 58.4 & 181 & 211.5 & 3,621 & \\
\hline $\begin{array}{l}\text { Federates States of } \\
\text { Micronesia }\end{array}$ & 112.6 & 702 & 344.5 & 3,058 & \\
\hline Nauru & 12.7 & 21 & 114.7 & 9,030 & \\
\hline Palau & 17.9 & 459 & 310,1 & 17,318 & \\
\hline Papua New Guinea & $8,606.3$ & 452,869 & $23,431.6$ & 2,723 & \\
\hline Samoa & 196.1 & 2,821 & 861.5 & 4,393 & \\
\hline Solomon Islands & 652.9 & 27,986 & $1,411.9$ & 2,163 & Y \\
\hline Timor-Leste & 1,268 & 14,919 & 2,581 & 2,036 & Y \\
\hline Tonga & 103.2 & 717 & 450.4 & 4,364 & \\
\hline Tuvalu & 11.5 & 26 & 42.6 & 3,701 & Y \\
\hline Vanuatu & 292.7 & 12,189 & 887.8 & 3,033 & Y \\
\hline
\end{tabular}

Source: * World Bank 2019

** Wikipedia https://en.wikipedia.org/wiki/List of countries and dependencies by area

In terms of economic vulnerabilities, small domestic markets, undiversified economies, usually limited endowment in natural resources, and remoteness form the global markets, renders those economies unattractive from the perspective of international capital and hence as a destination for foreign direct investment (FDI). Thus, they cannot become a part of global and regional value chains and this impacts their ability to advance development efforts, as engagement with the global economy (through, for example, international trade and sharing global production processes) is of particular importance for any 
contemporary development model. UNCTAD's World Investment Report (2019) emphasizes the fact that SIDS are a marginal destination for FDI (Table 2 and 3).

Table 2

FDI inflows in Pacific SIDS (2013-2018) (in US\$ millions)

\begin{tabular}{|l|c|c|c|c|c|c|}
\hline \multicolumn{1}{|c|}{ Country } & \multicolumn{7}{c|}{ FDI inflows } \\
\hline & $\mathbf{2 0 1 3}$ & $\mathbf{2 0 1 4}$ & $\mathbf{2 0 1 5}$ & $\mathbf{2 0 1 6}$ & $\mathbf{2 0 1 7}$ & $\mathbf{2 0 1 8}$ \\
\hline Fiji & 243 & 380 & 205 & 390 & 386 & 344 \\
\hline Kiribati & 1 & 3 & -1 & 2 & 1 & 1 \\
\hline Marshall Islands & 33 & -8 & -6 & -3 & 5 & -1 \\
\hline Federated States of Micronesia & & 20 & & & & \\
\hline Palau & 19 & 41 & 36 & 36 & 27 & 22 \\
\hline Papua New Guinea & 18 & -30 & 28 & -40 & -180 & 335 \\
\hline Samoa & 14 & 23 & 27 & 3 & 9 & 17 \\
\hline Solomon Islands & 53 & 22 & 32 & 39 & 43 & 12 \\
\hline Tonga & 51 & 56 & 12 & 9 & 14 & 8 \\
\hline Tuvalu & 0.3 & 0.3 & 0.3 & 0.3 & 0.3 & 0.3 \\
\hline Vanuatu & -19 & -18 & 29 & 22 & 24 & 38 \\
\hline
\end{tabular}

Source: UNCTAD World Investment Report 2019

Table 3

FDI inward stock in Pacific SIDS (2013-2018) (in US\$ millions)

\begin{tabular}{|l|c|c|c|}
\hline \multicolumn{1}{|c|}{ Country } & \multicolumn{3}{c|}{ FDI inward stock } \\
\hline & $\mathbf{2 0 0 0}$ & $\mathbf{2 0 1 0}$ & $\mathbf{2 0 1 8}$ \\
\hline Fiji & 356 & 2,978 & 4,781 \\
\hline Kiribati & & 5 & 14 \\
\hline Marshall Islands & 20 & 120 & 235 \\
\hline Federated States of Micronesia & & 7 & 442 \\
\hline Palau & 173 & 232 & 4,563 \\
\hline Papua New Guinea & 935 & 3,748 & 90 \\
\hline Samoa & 77 & 220 & 557 \\
\hline Solomon Islands & 106 & 552 & 446 \\
\hline Tonga & 19 & 220 & 8 \\
\hline Tuvalu & & 5 & 607 \\
\hline Vanuatu & 61 & 454 & \\
\hline
\end{tabular}

Source: UNCTAD World Investment Report 2019

In times of globalization and economic opening up, as well as integration of production processes through the international value chains, economies also become more vulnerable towards external shocks, as economic crises are swiftly transmitted from one corner of the world to another. Even those whose role in the international economic interaction is limited are inevitably affected. Their small size and undiversified economic structures make SIDS particularly vulnerable to these external economic shocks - global and regional financial and economic crises, fluctuations of global prices of certain goods and commodities and trade volumes, as well as shifts in global demand for certain services (e.g. tourism), due to, for example, a global recession. The recent Covid-19 pandemic is an illustrative example. The UNWTO (2020) estimates that the number of tourists globally will decrease by $60 \%$ to $80 \%$ in 2020 , will have a devastating effect on 
Pacific SIDS' development, as their national economies will inevitably experience significant recessions. This is because 'tourism earnings exceeded 50\% of GDP in Maldives and Palau and equalled approximately $30 \%$ of GDP in Samoa and Vanuatu. Similarly, the number of tourism employees constitutes more than $30 \%$ of total employment in Fiji, Palau and Vanuatu. While the full scale of the pandemic impact is still largely unknown, the possibility of double-digit contractions in GDP cannot be ruled out for Fiji, Palau, Samoa and Vanuatu in 2020' (Tateno and Bolesta, 2020, p. 3).

Environmental vulnerabilities relate to climate change and environmental degradation. Climate change is responsible for rising seas levels, unpredicted weather patterns, natural disasters (e.g. droughts, floods, etc.) and an overall change in environmental conditions. These occurrences impact SIDS' abilities to develop the agricultural sector, services (such as tourism) and necessary infrastructure. Natural disasters often deplete significantly the available resources and accumulated economic assets, reducing the overall GDP, as was the prominent case, for example, with cyclone Pam which devasted Vanuatu in 2015 and reduced its GDP by almost 65\% (ILO, 2015). Environmental degradation impacts the availability of resources, particularly for development of the so-called "Blue Economy" or the "Ocean Economy", which relies on the natural environment, as it reduces fish stock, pollutes sea water and degrades the overall natural habitat, which otherwise could have served as an important economic asset. It affects services such as tourism and contributes to the depletion of human capital due to deteriorating living conditions and the spread of diseases. In addition, addressing external environmental shocks related to global climate change is predominantly beyond the capacity of any given SIDS, making their degree of vulnerability even greater. Global changes in the natural environment can only be addressed by large polluters (which are also big economies) and concerted efforts by all the states. No matter how engaged SIDS become, their unilateral actions will not avert the process of climate change and worldwide environmental degradation.

Moreover, some Pacific islands, particularly Fiji, Papua New Guinea and Solomon Islands are affected by political instability and ethnic conflict (ESCAP, 2018). Papua New Guinea comprises of various ethnic groupings which speak around 850 different languages and dialects. Historically, the main ethnic conflict therein was related to the Bougainville civil war (1988-1998). The immigrant population in Bougainville, recruited mainly from representatives of Papua New Guinea's "mainlanders" increased as result of the mining sector development in the 1960s. As the new jobs were mostly awarded to the immigrant population and the benefits for the local population remained limited, by late 1988 tensions over the mining sector led to violence. The government deployed the military and fought against the rebels of the Bougainville Revolutionary Army (BRA). The conflict developed into a separatist insurgency. The estimated number of casualties among the local population was between 15,000 and 20,000. Papua New Guinea continues to be plagued by tribal unrests, tensions and conflicts, particularly in its mountainous interior, following largely tribal lines. In the Solomon Islands over 120 different languages and dialects are spoken. The main ethnic conflict (1999-2003) took place between the Gwale (inhabitants of Guadalcanal island) and the more recent immigrant population from the island of Malaita and concerned access to land and resources. The conflict abated with the intervention of foreign troops in 2003, but tensions continue to simmer. Fiji's population comprises indigenous Fijians who are mostly Melanesians (54\% of the population) and Indo-Fijians (38\% of the population) - immigrants brought by the British from the Indian Subcontinent at the time when it was part of the British Empire. The ethnic conflict between the indigenous Fijians and Indo-Fijians dates back to the early twentieth century and accelerated after Fiji's independence from Britain in 1970. Ethnic divisions were used, for example, as the motive for both the 2000 and 2006 coup d'états.

Social vulnerabilities concern growing populations of the Pacific and related social pressures on the labour market and beyond. The geographic dispersion and the remoteness of the populations impede effective delivery of social and public services. Some SIDS also face significant issues concerning gender inequality, with a significant prevalence of domestic and other violence against women. One of the most 
worrying cases is Papua New Guinea, where the majority of women have experienced some sort of violence. Indeed, particularly in conflict affected areas in SIDS the situation is precarious. For many women and girls, conflicts place greater restrictions on their choices, opportunities, movement and access to resources. Women and girls in conflict settings face an increased risk of violence - physical, sexual, economic and psychological (ESCAP, 2018).

As a result of existing economic, environmental, social and political vulnerabilities, and significant exposure to external shocks, Sustainable Development Goals - the UN General Assembly's sanctioned targets for sustainable development to be achieved by 2030 - are not being effectively implemented. In fact, ESCAP's Asia and the Pacific SDG Progress Report 2020 states that very few of the Goals are in track to be achieved (Goals 3, 9, 12), while some have even been regressing (Goals 8, 14, 16).

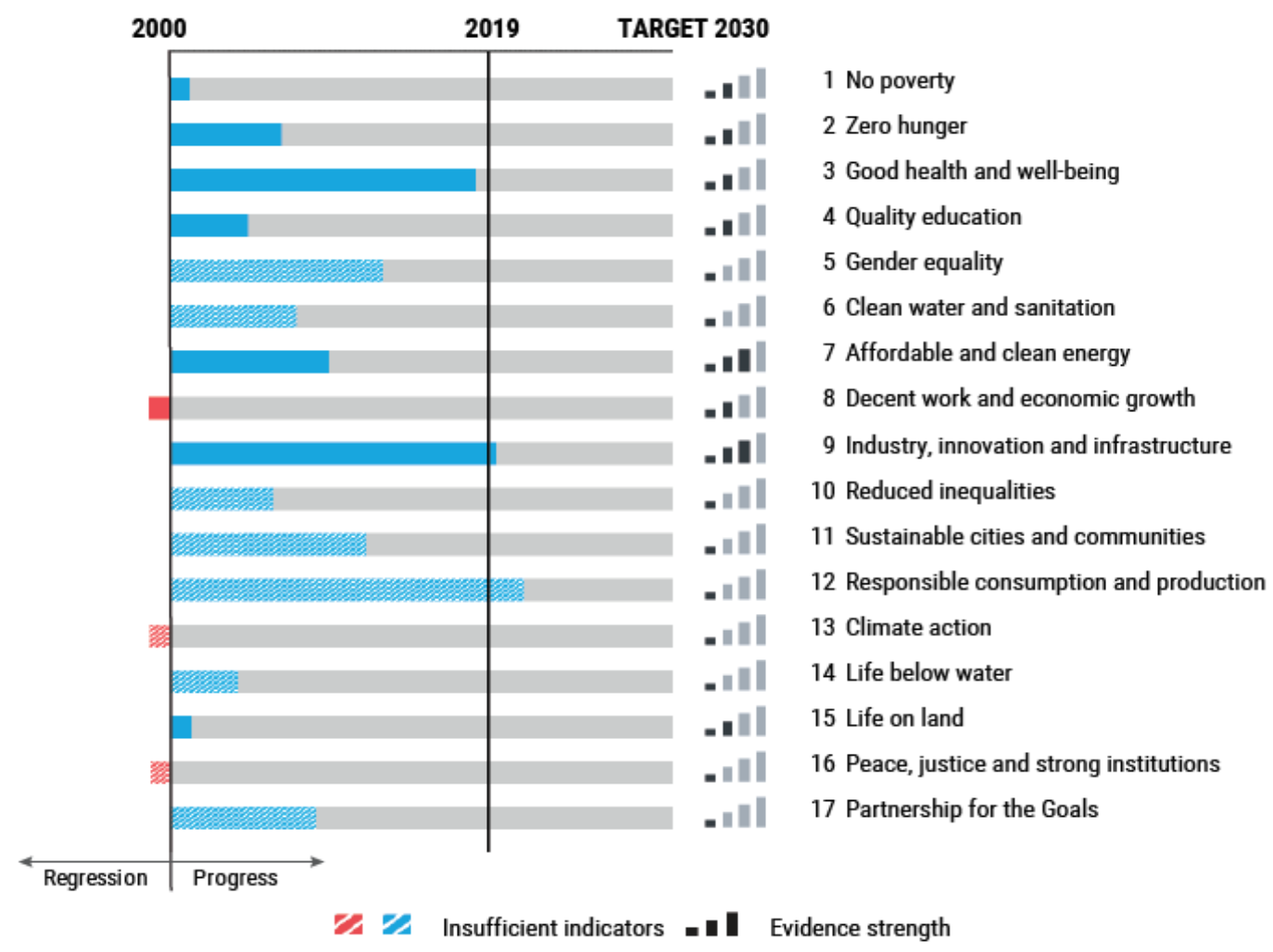

Figure 1. Progress in achieving Sustainable Development Goals in Asia-Pacific SIDS Source: SDG Progress Report 2020

ESCAP's Asia-Pacific Countries with Special Needs Development Report (2020a) argues that 'the success towards Goal 9 is mainly due to success in developing good-quality, reliable, sustainable and resilient infrastructure, including regional and transborder infrastructure, to support economic development and human well-being with a focus on affordable and equitable access for all' (p. 6), whereas 'small island developing States are grappling with providing their people with productive employment' (p. 7) and 'one reason that may explain the lack of progress $[\ldots]$ is the narrow resource base' (p. 8).

As a result, a discussion is needed as to the most effective policy solutions which ought to be implemented to mitigate negative trends, address the vulnerabilities and avert the negative situation allowing Pacific SIDS steady and effective developmental advancements. This discussion can be framed within three topic: (a) the international response to SIDS's development challenges as the SIDS' particular predicaments require concerted and coordinated efforts by the international community; (b) a genus of structural 
economic transformation - the overall prime engine of development - which will fit into SIDS' peculiar conditions; and finally, (c) taking into consideration these peculiarities, policies aimed at building and enhancing resilience towards various external shocks.

\section{THE INTERNATIONAL FRAMEWORK IN RESPONSE TO VULNERABILITIES}

The international community has paid significant attention to the development challenges of SIDS and provided subsequent policy support (see: ESCAP, 2020a, 2020b; World Bank 2017; UNCTAD, 2014). This is evident through special UN Programmes of Action, as well as the work of Special Representative in the rank of UN Undersecretary General, who heads an office specifically dedicated to Small Island Developing States, Least Developed Countries and Landlocked Developing Countries.

Although some SIDS' vulnerabilities can effectively be addressed through internal means and politics (e.g. implementation of redistributive policies to decrease social inequalities), many require broader, international engagement, as well as regional, and sub-regional cooperation (e.g. to overcome limited connectivity, and to alleviate exposure to environmental shocks). For example, on a number of occasions, an international transfer of knowledge and best practices will be required. Moreover, building resilience against broadly defined external shocks will necessitate the support of the international community and concerted international efforts.

Although it is clear that in view of environmental and climate catastrophes the response by the international community to SIDS development predicaments is by no means adequate, it is important to single out two particular action plans which fully or partially focus on addressing the development challenges of SIDS, namely, the SIDS Accelerated Modalities of Action (SAMOA) Pathway, which specifically focuses on small island states and the Istanbul Programme of Action, which concerns those Pacific islands which belong to the category of the Least Developed Countries (LDCs), as defined by a low level of development, high degree of economic vulnerability and limited human capital (DESA, 2018). Both Programmes of action are intricately linked to the United Nations' 2030 Agenda and the Sustainable Development Goals (SDGs), a collection of 17 global goals set by the United Nations General Assembly in 2015 for the year 2030, reflecting priorities and urgent areas, which need to be addressed by the international community.

The SAMOA Pathway (see: United Nations, 2014) acknowledges the existing and existential threats to SIDS related to environmental vulnerabilities such as climate change and violent weather patterns and calls for building resilience and the capacity to mitigate the effects of climate change and to improve monitoring and sectoral awareness. It mentions marine pollution and degradation of the natural environment, including its biodiversity. It calls for more efficient efforts at disaster risk reduction through technology transfer, increased sectoral investment, and adopting, mainstreaming and harmonizing adequate policies based on rigorous planning. However, it also goes further and specifically mentions that inherent development models need to be put in place to address SIDS development challenges - alluding to the necessity for a particular type of structural transformation - and these models need to underscore the need for sustainable, inclusive and equitable economic growth and the policies aimed at generating decent employment, creating enabling business environment to attract investment, and improving economic resilience. It also alludes to the concept of the "Blue Economy" (Chowdhury, 2019; ESCAP, 2019, 2020a), which focuses on the sustainable management of oceans and seas, its eco-systems and coastal zones. Finally, SAMOA Pathway emphasizes the importance of international cooperation and efforts in addressing the challenges and providing financial resources. International partnerships, institutional support and more efficient connectivity are of key importance to improving the means of implementation of policies to address development challenges, enhancing capacity building and statistics systems and enabling technology transfer. 
As far as the Istanbul Programme of Action (see: United Nations, 2011) is concerned, the LDC category was first introduced in 1971 and included one Pacific state, Samoa. The idea behind this was that countries characterized by low income ${ }^{3}$ and structural impediments were identified and awarded a special international status with privileges. These privileges have included:

(a) trade related support measures - preferential market access for goods through a duty-free, quota free (DFQF) mechanism as well as preferential tariffs and preferential and more flexible rules of origin for goods - the concept in itself being a response to the growing importance of the regional and global value chains and subsequent difficulty in identifying where a given product comes from; preferential treatment for services and service suppliers or the so-called "LDC services waiver", which essentially allows a non-reciprocity based approach for WTO members; special treatment regarding obligations and flexibilities under WTO rules to facilitate LDCs' compliance in view of limited institutional capacity and to protect policy space, as well as addressing supply-side constraints and supporting LDCs' broader engagement in international trade, as part of a development strategy;

(b) development cooperation, which concern commitments as far as bilateral overseas development assistance (ODA) flows to LDCs are concerned, multilateral cooperation and exclusive mechanisms, as many donors, national and international alike, define their obligations and legibility and make decisions on their support based on a country's status and its membership of the LDC category. Exclusive mechanisms include access to technology through LDC Technology Bank, access to funds for mitigating climate change through LDC Fund and climate change related expertise through LDC Expert Group, Aid for Trade through Enhanced Integrated Framework (EIF) to ease trade related constrains, United Nations Capital Development Fund to provide access to microfinance and investment capital, as well as Investment Support Programme for LDCs by IDLO and UNOHRLLS to provide capacity to LDCs;

(c) support for participation in the United Nations and other international forums, which include caps and discounts in contributions to the UN system budgets, support for travel, capacity building for participation in negotiations and flexibility in reporting requirements (DESA, 2018).

There are currently seven SIDS which are also LDCs; five of them are in the Asia-Pacific region. The recent success stories of SIDS graduating from the LDC category include Cabo Verde (2007), Maldives (2011) and, from the Pacific - Samoa (2014). Most of the current Pacific LDCs have already met the graduation criteria; during the 2018 triennial review Kiribati had done so for the third consecutive time (2012, 2015, 2018) and Timor-Leste and Solomon Islands for the second consecutive time. However, although Vanuatu (which met the criteria in 2006 and 2009 and then deferred graduation, on one occasion due to cyclone Pam) is scheduled to graduate in 2020 and Solomon Islands in 2024, Timor-Leste was not recommended for graduation and this case will be reviewed again in 2021. Moreover, it is argued that the COVID-19 pandemic and its devastating effect on SIDS's economies (see: ESCAP, 2020b, 2020c; Tateno and Bolesta 2020; UNWTO 2020), the graduation may be postponed.

SIDS' development vulnerabilities have prompted a debate as to the criteria for graduation from the LDC category. All SIDS LDCs have been recommended for graduation based on the GNI per capita criterion and human assets criterion and not on the economic vulnerability criterion (the three criteria define the eligibility for graduation; see: (DESA, 2018). In fact, it is unlikely that despite the graduation from the LDC category, in the foreseeable future SIDS will meet the economic vulnerability criterion, due to

\footnotetext{
${ }^{3}$ Low income status is not equal to belonging to the LDC category. In fact, none of the Pacific LDCs are low income economies;
} all are lower middle-income countries. 
economic and environmental reasons. First, they are small and undiversified economies whose budget revenue and thus capacity to spend will be affected by global price fluctuations and global incomes fluctuations (which affect tourist flows). Second, natural (e.g. extreme weather conditions) and man-made disasters (environmental degradation) will affect their capacities to grow and can cause extensive loss of economic stock and assets. Consequently, a new Programme of action is needed to award SIDS international privileges regardless of their LDC status, if the international community is to effectively support the most vulnerable among SIDS.

Moreover, there is a growing consensus that the next UN Programme of Action for LDCs (so-called LDC-V or the Doha Programme of Action, as the programme will be agreed upon in the capital of the State of Qatar) that among the priorities should be structural economic transformation, as the key component of developmental advancements and the process, in which the majority of LDCs have lagged behind.

\section{STRUCTURAL ECONOMIC TRANSFORMATION}

The Istanbul Programme of Action acknowledges the importance of structural transformation in addressing the development challenges of least developed countries. Structural economic transformation a gradual increase in value addition of the output of a given economy - lies at the centre of developmental advancements. This concerns structural transformation within sectors (i.e. agriculture, industry, services) or one sustained through shifts between sectors, traditionally from agriculture to industry and then to services. Once an economy moves towards producing more sophisticated goods, the demand for skilled labour increases. Skilled jobs are also better paid; hence, the population increases its purchasing power and wealth and poverty is reduced. Naturally, there are additional conditions which determine the societal ability to engage with and benefit from the restructuring of an economy; these include: employability of the labour force determined by its skills. Nevertheless, the level of wealth within a population is, to a large degree but with some significant exceptions, dependent on the degree of the sophistication of a national economy.

Studies reveal that in terms of poverty reduction, in the short term, it is the shift within sectors which brings better results (ESCAP, 2019) and particularly within agriculture and this conclusion has indeed important consequences for small island developing States, whose structural shifts between sectors have faced various challenges. Naturally, in the long term, the gradual move from agriculture to industry and then to services is, nevertheless, necessary. Moreover, research shows that greater productivity gains and employment generation, thus poverty reduction, come from transformation from agriculture to industry rather than from agriculture straight to services (ESCAP, 2016). This conclusion creates an additional development challenge for SIDS, as SIDS' structural transformation is often characterised by a move from agriculture to services. Indeed, the relocation of the labour force from agriculture to manufacturing always means the multiplication of productivity, whereas the move between agriculture to services often results in rural poverty being replaced by urban poverty.

There are various challenges to effective structural transformation. Two of them have been of critical importance in recent years. First, in terms of poverty reduction, the contemporarily observed phenomenon of an early de-industrialization, in which economies shift from manufacturing to services at a lower level of GDP per capita and at a lower share of industry in the overall GDP, as compared to the experiences of the earlier industrialisers (Rodrik, 2018; Popov and Chowdhury, 2016; Bolesta, 2019), is indeed worrying. Early de-industrialization affects efforts at poverty reduction, as it is manufacturing which brings the best results in increasing wages. Second, the often observed move from unproductive agriculture to unproductive services does not reduce poverty either, as it omits the vital stage of industrial development. In other words, inhabitants of rural areas, formerly employed in agriculture, move to cities and engage in activities such as delivery services, cleaning, etc. From an economic perspective, their new jobs are as unproductive as those 
they left behind (ESCAP, 2019). Consequently, despite the move to urban areas and change in type of employment, they remain poor.

The traditional path of structural transformation from agriculture to industry and then to services is, unfortunately, not viable for the majority of SIDS. In most of the SIDS, particularly the remotely located Pacific islands, creating an industrial manufacturing base (focused on export) is not feasible. As discussed earlier, the costs of reaching international markets are too high. This impedes availability of FDI and thus affects capital formation and technology diffusion. Hence, often direct transformation from agriculture to services is necessary. In that case, one needs to avoid a transfer which will not have a positive influence on productivity, as has been the case in many developing Asian economies. Moreover, the solution may lie in modernization and sustainability of the agriculture, and in particular, the fishery sector, as this may bring extensive gains in poverty reduction (see: ESCAP, 2020a). It is worth noting that the size of Pacific SIDS' exclusive economic zones (EEZ) combined, which includes their exclusive rights to water areas, is 31 times bigger than their landmass. EEZ thus constitute a significant asset. Hence, the structural transformation in Pacific must deviate from the traditional path and omit the industry development period, focusing instead on services (addressing the predicaments of the rural poor becoming urban poor due to the lack of improvements in productivity) and on (modernized and more productive) agriculture.

\section{The traditional pattern:}

SIDS' required pattern:

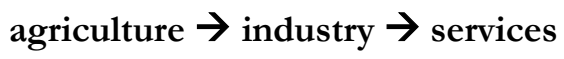

\section{Figure 2. Structural economic transformation - the traditional patterns and the SIDS' required pattern}

Indeed, a study by the ESCAP (2019) acknowledged the necessary peculiarities of structural transformation in SIDS and among the sectors for targeting to overcome the development challenges in the most effective way, identified productive services and modern agriculture, and more specifically:

- the environmentally sustainable oceanic resource management, known as the "Blue Economy", in a manner which supports development of local/indigenous micro, small and medium enterprises (MSMEs) and ensures that a significant portion of economic gains is maintained domestically. As mentioned, EEZ constitute a significant economic asset. However, the fee paid for usage of the SIDS' waters by international companies and corporations and other states is still a fraction of the revenue the latter gain from these activities. For example, in 2014, 12 small island developing Pacific governments received only $\$ 331$ million in revenue from access fees to their EEZs, compared to the value of the extracted tuna therein of approximately \$2.5 billion in 2016 (Gillett, 2016; PIFFA, 2017);

- Second, despite the remoteness and high costs of reaching these islands, tourism is a viable option due to the natural richness of the region with unique and well-preserved fauna and flora. However, for it to be environmentally sustainable and serving the purpose of generating productive employment, tourism must be a Bhutan-style regulated low-impact, high-value industry, in which quotas are set and impact on the natural environment is minimal;

- Third, for larger landmass SIDS, such as those based in Melanesia, commercial crop production for export markets might be suitable. This would be in line with the UNCTAD's 2018 LDC Report's general suggestions on the commercialization of LDCs' rural economies. Successful cases include 
beef production in Vanuatu for the Australian market and the sugarcane industry in Fiji (ESCAP, 2019).

Moreover, ESCAP's (2020a) Asia-Pacific Countries with Special Needs Development Report Leveraging Ocean Resources for Sustainable Development of Small Island Developing States has concluded that the two main sectors to be further developed to enable effective developmental advancements in Pacific SIDS are "local content intensive" tourism and fisheries, as those who can provide the most benefits for local populations and local economies. It is, important, however, that both sectors provide productive employment. This can be achieved if tourism development is geared towards marine, culture-based and sports tourism sectors, in which local populations are not only subsidiary actors, but play leading ownership role. In fisheries, one should ensure the same position in the industry, not only in coastal fishing, but also beyond.

\section{SUPPORTING ECONOMIC POLICIES}

The task of identifying necessary sectors for development and the most suitable path of structural economic transformation is only the beginning. The next step concerns adequate long-term economic policies, which will allow for sectoral development.

First, SIDS must enhance their resilience against and reduce susceptibility to external shocks, as indicated in the Programmes of Action (United Nations, 2011, 2014). Building resilience is an arduous, multi-layered and multidimensional process, which requires the concerted efforts of national, international and other state holders. This process is, however, indispensable for ensuring inclusive and sustainable development. The sectoral discussion concerns the role of international community versus national governments. In terms of economic shocks, efforts cannot be limited to standard, often anticyclical, national macroeconomic policies. They need to include designing a tailored development strategy, which takes into consideration comparative advantage and domestic strengths, but at the same time presents a vision beyond comparative advantage and one which considers external and internal factors which may contribute to or inhibit efforts. A separate issue concerns the ability to build resilience towards global and regional financial crises. This must remain the domain of the international community and the plausible policy options must contain more thorough regulation of international financial flows, scrutiny over the financial sectors' products and more effective monitoring of sectoral activities. The role for SIDS and LDCs to build resilience in this respect, may mean to rely, to a greater extent, on sources of financial flows from fast growing emerging economies, regulate the transfers domestically and favour, through domestic incentives, those flows which contribute to sustainable and inclusive growth, such as FDI generating positive externalities (e.g. productive employment and the development of the local business sector). What will improve resilience against the volatility of financial markets is a low level of external debt and its sustainability, hence the government's macroeconomic policies must be prudent and ensure the sustainability of its external obligations. In SIDS, public debt servicing takes up a significant share of state revenue, and those resources could be used for productive purposes. De-dollarization may give the authorities more policy options, however, it may also expose small economies to currency shocks.

Second, for LDCs and many other SIDS, the biggest overall concerns in terms of progressing with structural economic transformation and developmental advancements lie with the limited productive capacities, defined by UNCTAD (2018) as: productive resources (human, financial, natural, physical), entrepreneurial capabilities and production linkages, the latter defined broadly as networks, also within regional value chains (RVC) and global value chains (GVC), backward and forward linkages, production clusters, resource networks, links between FDI and the domestic business sector, and between firms. UNCTAD (2018) lists the biggest challenges to building productive capacities: limited domestic demand 
growth (poverty), a lack of human capital (knowledge), a lack of productive employment, a lack of resources (capital) and a lack of a supportive financial system (intermediary infrastructure).

The policies aimed at building the productive capacities must therefore address those challenges, through (a) creating a necessary soft and physical infrastructure, including a well-regulated financial sector; (b) creating an enabling economic environment for the business sector to thrive and FDI to be attracted, with, however, a particular focus on domestic sector development through various linkages (e.g. GVC and RVC) to the global economy. Although, as illustrated, attracting FDI to SIDS is an arduous task, the development of the identified sectors will require the inflow of capital and know how. Moreover, in order to implement any effective policies and build capacities, (c) an effective reporting/statistics system must be in place.

Third, in the SIDS context, one needs to focus on rural modernization as part of structural transformation. LDC Report 2018 suggests aligning agricultural economy with market and economic activities and making it more business oriented and thus an integral part of the overall economy, rather than playing the traditional role of "feeding the population". This is important as rural modernization will, in the short term, bring more extensive poverty reduction results than other efforts within structural transformation (ESCAP, 2019). This rural modernization must encompass a broad range of policies which will enable and secure land property rights, mechanization, dissemination of sectoral technology and advanced technics and most productive inputs (grains, etc.) of farming and husbandry. It also needs to be supported by targeted financial services for farmers and the rural economy.

This assertion is backed by empirical studies that 'found a large elasticity of poverty with respect to agricultural output, especially in countries at the early stages of development' (ESCAP, 2019). According to Christiaensen, Demery and Kuhl (2011) agriculture growth is two to three times more effective at reducing poverty than an equivalent amount of growth generated in other sectors (ESCAP, 2019). This is explained by Norbu, Tateno, Bolesta (2019) who examine the strong positive association between agricultural productivity and its backward linkage with other sectors. Indeed, as agricultural productivity increases, its backward linkages usually increase by requiring more machinery, high quality fertilizers, transport equipment and financial services. This suggests that the more productive the agriculture sector is, the larger the benefits that other sectors can enjoy, and thus the more inclusive and sustainable rural development becomes (Norbu et al. 2019).

Fourth, structural transformation itself may not contribute to employment generation. Hence it needs to lead to the development of labour intensive sectors. This poses additional challenges for SIDS, as the most desirable sector would be manufacturing, an option not viable for them. Instead, SIDS must focus on services. In this respect, the state policy must address the binding constraints to employment creation such as infrastructure and skills. The question of productive and decent employment must be addressed from the supply and demand side. On one hand, an educational system must be created and an education strategy designed which will allow for a steady increase in the quality of human capital in the long term, ensuring a supply of skilled labour force to the market. However, the education system must also be designed to address domestic market needs (the demand side) rather than be focused exclusively on gradual improvements of skills in general. This means that what needs to be considered for the education strategy is the domestic comparative advantages of the local economy and/or the state vision as to the engaging of latent comparative advantages or indeed creating new ones. The envisaged development trajectory is determined by various economic, geo-political, geographical and historical factors, including features of the existing economy, regional and global trends, and the elites' perceptions as to the new opportunities.

Fifth, although the Addis Ababa Action Agenda (see: United Nations, 2015) stipulates that the main responsibility for financing for development lies within the national governments, it is by all accounts clear that many SIDS, particularly LDCs, do not possess and cannot domestically generate adequate resources to 
advance development. Moreover, although it is argued on international forums that development assistance should foremost be provided by advanced economies, the problem is compounded by the stagnation of official development assistance (ODA) and little political prospects to avert the situation. Moreover, in terms of development of the financial markets, SIDS economies seem to be too small, hence the efforts would need to include building regional structures rather than national structures (e.g. a regional stock exchange). The solution might thus lie in other mechanisms such as remittances and South-South cooperation. Remittances have traditionally been a source of financing for many SIDS with their diasporas around the world, contributing, for example, to Tonga's economy as much as over 40\% of GDP (Table 4).

Table 4

Personal remittances received (as \% of GDP)

\begin{tabular}{|l|c|c|}
\hline \multirow{2}{*}{ States } & \multicolumn{2}{|c|}{ Remittances (\% of GDP) } \\
\cline { 2 - 3 } & 2010 & 2018 \\
\hline Fiji & 5.6 & 5.2 \\
\hline Kiribati & 10.0 & 9.7 \\
\hline Marshall Islands & 13.7 & 14.1 \\
\hline Federated States of Micronesia & 6.1 & 7.1 \\
\hline Palau & 0.9 & 0.8 \\
\hline Samoa & 20.9 & 16.1 \\
\hline Solomon Islands & 5.6 & 1.2 \\
\hline Timor-Leste & 15.6 & 3.4 \\
\hline Tonga & 20.0 & 40.7 \\
\hline Tuvalu & 12.3 & 9.5 \\
\hline Vanuatu & 1.7 & 2.2 \\
\hline
\end{tabular}

Source: World Bank 2019

Indeed, these financial flows need to be maintained. However, remittances are mostly used for household consumption, and although this may incentivize an increase in domestic production, per se they contribute little if anything to building domestic productive capacities. The way to employ remittances to build productive capacities would be through regulating (e.g. taxing) the remittances flows, which is in itself a contentious issue, often politically not viable. To more effectively employ remittances for developmental advancements, one may consider building a more enabling business environment so that remittance recipients may wish to invest their resources rather than spend them on current consumption.

Moreover, in view of the emerging economic clout of some large developing economies such as China and India, South-South cooperation may arise as an important source of financing for development for SIDS. Although the international community is adamant about South-South cooperation being merely complementary to such efforts as ODA by advanced economies, the eagerness of economic expansion of large emerging economies, as well as their financial capacities can make South-South cooperation a potentially indispensable source of financing for development. The vehicles for such assistance already exist; for example, the New Development Bank (created by BRICS countries) and the China-led Asian Infrastructure Investment Bank, which already provide loans. Some national development banks have also engaged in financing development projects in SIDS, notably the China Development Bank and China Import-Export Bank whose funds dispersion is greater than that of the World Bank. Sustainability questions aside, these new mechanisms may become the leading source of development assistance.

Finally, domestic efforts to improve financing for development must concentrate on building an efficient financial system, which will enable credit access, particularly to macro, small and medium sized 
domestic enterprises (MSME), and particularly those who target productive employment and innovation. Closing the gaps in the taxation system and eliminating informal sectors, at the same time simplifying procedures, will result in greater financial flows to governments, which can in turn use the funds for development.

\section{CONCLUSION}

In recent decades, economic growth in Pacific small island developing States has allowed for important developmental advancements. It is very likely that within the next decade all Pacific LDCs will graduate from the category of Least Developed Countries. All of them already belong to the group of middle-income economies.

Nevertheless, the current situation looks for SIDS precarious, as evidenced by a lack of progress in Sustainable Development Goals. This is due to external economic and environmental shocks, the latter causing threats of existential proportions, and due to other factors, examined in this article, which impede growth. Hence SIDS' governments' pleas for greater efforts to amend the situation, as indeed the progress may be stalled and some of the countries may cease to exist within the next decades due to rising sea levels, the result of the climate change. Indeed, SIDS development trajectories are already negatively affected by various factors, which may lead to the deterioration of economic conditions. To add to the development predicaments, external economic and environmental shocks cannot be mitigated by domestic efforts only. They require combined efforts within the international community as well as closer regional cooperation and collaboration. But the international community seems slow in acting to mitigate climate change effects and indeed in averting the process.

However, SIDS's cannot sit idly and indeed they do not. SIDS' domestic policies may be seen as equally important for coping with external shocks and internal predicaments and undoubtedly may add to the solutions towards addressing their development challenges. Firstly, structural economic transformation, a necessary process to reduce poverty and advance development, must be tailored to the specific needs of Pacific islands and deviate from the traditional patterns. It must be focused on modernizing agriculture and building a robust "Blue Economy" focused on sustainable fishery within SIDS' exclusive economic zones (EEZ). By skipping the development of the manufacturing sector, the process must also focus on developing services. These services must, however, be characterized by increased productivity. This can be achieved through the expansion of a particular type of tourism, one yielding high revenue not from the volume of visitors but from the quality of service, one which is tightly regulated to minimize the impact on the natural environment and to ensure environmental sustainability. The Bhutan model is there to be studied and may be useful. The specific targeting of sectoral development must be supported by more general economic policies implemented by a capable state. These policies include: building economic resilience and productive capacities and ensuring that, in the process, productive employment is created in the new and modernized sectors of a national economy. At the same time, one needs to utilize new mechanisms for harnessing financial resources to enhance the development trajectory.

\section{ACKNOWLEDGEMENT}

The views expressed herein are those of the author and do not necessarily reflect the views of the United Nations. 


\section{REFERENCES}

Bolesta, A. (2015). China and Post-Socialist Development. Bristol: Policy Press.

Bolesta, A. (2019). From socialism to capitalism with communist characteristics: the building of a post-socialist developmental state in Central Asia, Post-Communist Economies.

Brown, M.A. (2006). Development and security in the Pacific island region. Policy paper. The Security-Development Nexus Programme. International Peace Academy.

Chowdhury, A. (2019). Structural transformation and its role in poverty reduction in the Asia-Pacific Countries with Special Needs: A differentiated approach. A background paper prepared for the Asia-Pacific Countries with Special Needs Development Report. Bangkok: United Nations Economic and Social Commission for Asia and the Pacific.

Christiaensen, L., Demery, L., \& Kuhl, J. (2011). The (evolving) role of agriculture in poverty reduction: An empirical perspective. Journal of Development Economics, 96(2), 239-254.

DESA. (2018). Handbook on the Least Developed Country Category: Inclusion, Graduation and Special Support Measures, third edition. New York: United Nations Department of Economic and Social Affairs www.un.org/development/desa/dpad/wp-content/uploads/sites/45/2018CDPhandbook.pdf.

Devadason, C.A., Jackson, L. \& Cole, J. (2019). Pacific Island Countries: An Early Warning of Climate Change Impacts. Oxford: Report from the Secretariat of the Rockefeller Foundation Economic Council on Planetary Health.

ESCAP. (2016). Economic and Social Survey of Asia and the Pacific (2016): Nurturing productivity for inclusive growth and sustainable development. Bangkok: ESCAP.

ESCAP. (2018). Asia-Pacific Countries with Special Needs Development Report 2018: Sustainable Development and Sustaining Peace. Bangkok: ESCAP.

ESCAP. (2019). Asia-Pacific Countries with Special Needs Development Report 2019: Structural Transformation and its Roel in reducing Poverty. Bangkok: ESCAP.

ESCAP. (2020a). Asia-Pacific Countries with Special Needs Development Report 2019: Leveraging Ocean resources for Sustainable Development of Small Island Developing States. Bangkok: ESCAP.

ESCAP. (2020b). Changing Sails; Accelerating Regional Actions for Sustainable Oceans in Asia and the Pacific. Bangkok: ESCAP. ESCAP (2020c). Economic and Social Survey of Asia and the Pacific 2020: Towards sustainable economies. Bangkok: ESCAP.

FAO. (2016). The State of World Fisheries and Aquaculture 2016: Contributing to Food Security and Nutrition for All. Rome: Food and Agriculture Organization www.fao.org/3/a-i5555e.pdf.

FAO. (2018). The State of World Fisheries and Aquaculture 2018: Meeting the Sustainable Development Goals. Rome: Food and Agriculture Organization. www.fao.org/3/i9540en/i9540en.pdf.

Firth, S. (2018). Instability in the Pacific Islands: A status report. Sydney: The Lowy Institute.

Gillett, R. (2009). Fisheries in the Economies of the Pacific Island Countries and Territories. Manila: Asian Development Bank. www.adb.org/sites/default/files/publication/27511/pacific-fisheries.pdf.

Gillett, R. (2016). Fisheries in the Economies of Pacific Island Countries and Territories. Second edition. Noumea: Pacific Community.

Holland, B.S., \& Kay. E.A. (2013). The Pacific Islands: Environment and Society. In: Rapaport. M. (ed.). The Pacific Islands: Environment and Society. University of Hawaii Press, Chapter 7, 83-94.

ILO. (2015). Cyclone PAM causes devastating impact on employment and livelihoods. ILO Disaster Preparedness and Response. https:// wmw.ilo.org/suva/public-information/WCMS 368560/lang-en/index.htm.

Maddison, A. (2007). Contours of the World Economy 1-2030 AD: Essays in Macro-Economic History. Oxford: Oxford University Press.

LDC Report. (2018). The Least Developed Countries Report 2018: Entrepreneurship for structural transformation: beyond business as usual. Geneva: UNCTAD.

Lum, T., \& Vaughn. B. (2017). The Pacific Islands: Policy Issues. Congressional Research Service Report. Washington, D.C.

Norbu, N.P., Tateno, Y., \& Bolesta, A. (2019). Structural transformation, poverty reduction, backward and forward linkages and job creation in Asia-Pacific least developed countries: an input-output analysis. Paper presented at the UNU-WIDER Development Conference, 11-13 September 2019, Bangkok.

Organisation for Economic Co-operation and Development (OECD). (2016). The Ocean Economy in 2030. Paris: OECD. $20305 j \mathrm{~m} 55 \mathrm{j} 26 \mathrm{brg} 3$.pdf?itemId=\%2Fcontent $\% 2 \mathrm{Fpublication} \% 2 \mathrm{~F} 9789264251724$-en\&mime-Type $=$ pdf. 
PIFFA. (2017). Value of WPCO tuna fisheries 2017. Pacific Islands Forum Fishery Agency, www.ffa.int/node/425 (accessed: 16/07/19).

Popov, V. \& Chowdhury, A. (2016). What can Uzbekistan tell us about industrial policy that we did not already now?, DES A Working Paper, 147.

Pratt, S. (2015). The economic impact of tourism in SIDS. Annals of Tourism Research, 52 (May), pp. 148-160.

Pratt, S. (2019). Raising financing through ocean resources to foster sustainable development of small island developing States: the role of tourism. Background paper prepared for the Asia-Pacific Countries with Special Needs Development Report: Leveraging Ocean Resources for Sustainable Development of Small Island Developing States. Bangkok: ESCAP.

Rodrik, D. (2018). Straight Talk on Trade: Ideas for a Sane World Economy. Princeton: Princeton University Press.

SDG Progress Report. (2020). Asia and the Pacific SDG Progress Report 2020. Bangkok: ESCAP. https://www.unescap.org/publications/asia-and-pacific-sdg-progress-report-2020

Tateno, Y., \& Bolesta, A. (2020). Addressing the impact of the pandemic on tourism in Asia-Pacific small island developing States, MPFD Policy Briefs, 111.

UNCTAD. (2014). The Oceans Economy: Opportunities and Challenges for Small Island Developing States. Geneva: UNCTAD.

UNCTAD. (2018). Achieving the Sustainable Development Goals in the Least Developed Countries: A Compendium of Policy Options. Geneva: UNCTAD.

UNCTAD. (2019). World Investment Report 2019: Special Economic Zones. Geneva, UNCTAD.

United Nations. (2011). Programme of Action for the Least Developed Countries for the Decade 2011-2020. United Nations. Istanbul. http://unohrlls.org/UserFiles/File/IPoA.pdf

United Nations. (2014). SIDS Accelerated Modalities of Action (S.A.M.O.A.) Pathway https://unohrlls.org/customcontent/uploads/2015/01/SAMOA-Pathway.pdf

United Nations. (2015). Addis Ababa Action Agenda of the Third International Conference on Financing for Development https://www.un.org/esa/ffd/wp-content/uploads/2015/08/AAAA Outcome.pdf

UNWTO. (2019). Tourism in Small Island Developing States (SIDS): Building a More Sustainable Future for the People of Islands. Geneva: World Tourism Organization. www.e-unwto.org/doi/pdf/10.18111/9789284416257.

UNWTO. (2020). UNTWO World Tourism Barometer May 2020: Special Focus on the Impact of COVID-19 (Summary). https://webunwto.s3.euwest-1.amazonaws.com/s3fs-public/2020-05/Barometer\%20\%20May\%202020\%20-\%20Short.pdf.

World Bank. (2017). The Potential of the Blue Economy: Increasing Long-term Benefits of the Sustainable Use of Marine Resources for Small Island Developing States and Coastal Least Developed Countries. Washington, D.C.: The World Bank.

World Bank. (2019). World Bank database https://data.worldbank.org/ (accessed: 16/07/19). 